\title{
CZYM SĄ MARKSISTOWSKIE BADANIA SZKOLNICTWA WYŻSZEGO?
}

KRYSTIAN SZADKOWSKI I JAKUB KRZESKI

Ile razy słyszeliśmy już, że uniwersytet pogrążony jest w kryzysie? Od kilku dekad autorzy i autorki z całego spektrum politycznego sporu prześcigają się w tworzeniu kolejnych narracji na jego temat. Korporatyzacji (Schrecker 2010), utowarowieniu (Oliveira 2013), prywatyzacji (Ball i Youdell 2008), urynkowieniu (Jongbloed 2003) i ekspansji kapitalizmu akademickiego w murach uniwersytetu (Leslie i Slaughter 1998) przeciwstawia się najczęściej postulaty wzmocnienia publicznego charakteru instytucji szkolnictwa wyższego (Barnett 2015) czy ich powtórnego upublicznienia (Marginson 2006). Tymczasem wszystkie te perspektywy wydają się tkwić w pułapce liberalnego imaginarium, są uwięzione w konceptualnym horyzoncie, na który składa się liberalna filozofia polityczna i klasyczna ekonomia polityczna.

Koncentrując się na marksistowskim pojęciu krytyki, chcielibyśmy poświęcić uwagę szczególnemu nurtowi badań nad kryzysem uniwersytetu, który przekracza ograniczenia wspomnianych perspektyw. W ten sposób pragniemy przybliżyć ogólną ramę, w której problemy uniwersytetu umieszczają autorzy i autorki tekstów składających się na niniejszy numer. Wszystkie przynależą do nurtu marksistowskich czy krytycznych badań nad szkolnictwem wyższym, powstałych w odpowiedzi na doświadczenie kryzysu uniwersytetu odczuwanego zarówno przez jego pracowników, jak i samych studentów i studentki. To, co jednak wyróżnia go na tle wielu innych podejść, to fakt, że z jednej strony wyrasta z wielu 
frontów walk o konkretną alternatywę dla pogrążonego w kryzysie uniwersytetu, prowadzonych zarówno na poziomie krajowym, jak i międzynarodowym, z drugiej zaś, że usiłuje przekroczyć niedostatki liberalnych narracji. Spróbujemy zatem odpowiedzieć na tytułowe pytanie: czym są marksistowskie badania nad szkolnictwem wyższym?

\section{Uniwersytet jako kapitalistyczny sektor produkcji}

Głównym przedmiotem zainteresowania, inaczej niż dla różnego rodzaju marksistów, nie jest rola szkolnictwa wyższego i badań naukowych w rozwoju przemysłowej produkcji kapitalistycznej. Marksistowskie czy krytyczne badania szkolnictwa wyższego nie idą zatem śladem ani Louisa Althussera (2006), który instytucję szkolnictwa wyższego ulokował w obrębie aparatów ideologicznych państwa, ani Ernsta Mandela (1999, 248-273) wskazującego na coraz większe znaczenie badań stosowanych w erze późnego kapitalizmu czy Glenna Rikowskiego (1997), który rozwinął współczesną marksistowską teorię produkcji siły roboczej w kontekście szkolnictwa wyższego.

Jedno z głównych założeń, stojących za interesującym nas nurtem badawczym, mówi bowiem, że w przeciagu ostatnich lat sektor szkolnictwa wyższego i nauki (w tym instytucja uniwersytetu) przeistoczył się w obszar kapitalistycznej produkcji per se. Uniwersytet stał się przestrzenią, w której kapitał bezpośrednio ulokował proces pomnażania wartości w oparciu o pracę akademicką. Tym samym wykonywana w jego ramach praca, za pomoca złożonych mechanizmów, została poddana subsumcji pod kapitał, a następnie włączona w jego cyrkulację i akumulację.

To, że uniwersytety czy system szkolnictwa wyższego jako całość stają się w coraz większym stopniu miejscem produkcji kapitalistycznej, nie oznacza jednak, że marksistowscy badacze rozważają te procesy w kategoriach transformacji uniwersytetu w fabrykę (Edu-factory 2011). Gdy kapitał wkracza w nowy obszar życia i społecznej aktywności, adaptuje się do istniejących w danym polu form organizacji, by móc realizować swój cel samopomnażania. Kapitał jest elastyczną siłą, która podporządkowując sobie dany obszar, najpierw włącza go wraz z właściwą mu dynamiką (formalna subsumcja), a następnie przekształca i formuje na własne podobieństwo (realna subsumcja) (Marks 1956; Szadkowski 2015a). Jednak ta rzeczywista dynamika sektora - istniejąca i funkcjonująca przez całe stulecia w przedkapitalistycznych formach ekonomii praxis - pozostaje punktem odniesienia dla procesów kapitalistycznych w podporządkowanym sektorze. W tym sensie takie elementy jak ekonomia prestiżu, szczególna forma cyklu produkcyjnego (rok akademicki, podział na semestry etc.), pozostają w obrębie rzeczywistości kapitalistycznej nowych sektorów. Efekt w niczym nie przypomina jednak modelu produkcji przemysłowej, który przyjąć miałoby szkolnictwo wyższe i nauka. W tym sensie ilustrowanie przekształceń tego sektora za pomoca obrazów 
przedstawiających fabryki, linie produkcyjne i toporne maszyny wtłaczające kadrę akademicka i studentów w swoje tryby jest co najmniej mylące.

Trzeba również zauważyć, że przyglądając się hegemonicznemu dyskursowi nad współczesnym uniwersytetem (uniwersytetem przedsiębiorczym, multiwersytetem etc.) czy modelom reform (np. nowemu zarządzaniu publicznemu), głównonurtowi badacze szkolnictwa wyższego dostrzegają daleko posunięte procesy hybrydyzacji (por. Szadkowski 2015b). Z kolei globalne procesy instytucjonalnego izomorfizmu (Antonowicz 2015) czy dialektyki między homogenizacją a heterogenizacją, występujące w ramach krajowych systemów, w oczach krytycznych badaczy przyjmują formę kolejnych fal neoliberalnej restrukturyzacji sektora publicznego, która jest początkową fazą rozszerzania stosunków kapitalistycznych.

\section{Uniwersytet i kryzys}

Kryzys jest immanentną cechą funkcjonowania kapitału, a współczesny uniwersytet tkwi w jego objęciach. Zgodnie z logiką wyłożoną przez Marksa, kryzys jest odpowiedzią kapitału na napotkane przeszkody, który daje możliwości dalszych transformacji. Jak wskazał David Harvey: „kryzysy są momentami transformacji, w których kapitał zazwyczaj wymyśla siebie na nowo i przemienia w coś nowego" (2014, 4). A jednak, to właśnie podczas kryzysów najważniejsze sprzeczności systemu są w pełni widoczne. W przypadku uniwersytetu, sytuacja ta wprowadza rodzaj niepewności, która stwarza okazję zarówno dla akademickich wytwórców, jak i zaangażowanego w uniwersytet kapitału.

Uniwersytet podporządkowany kapitałowi jest uniwersytetem znajdującym się w długotrwałym kryzysie, „systematycznym kryzysie, który jest strukturalny w swojej naturze (...) i ma potencjał doprowadzenia do starcia sił społecznych, które wyłaniają się z niezdolności w skali globalnej do rozwiązania jego przyczyn i skutków" (Hall 2015, 7). Kryzys ten odnosi wymiar niestabilności globalnego systemu kapitalistycznego jako całości do wyłaniających się ruchów protestu, które stawiają opór. John Holloway (2010) przybliża nam to szczególne rozumienie kryzysu, nawiązując do hasła „To my jesteśmy kryzysem!”, które regularnie pojawiało się podczas protestów studenckich przeciwko sytuacji na uniwersytecie, jak również dominacji kapitału nad uniwersytetem i gospodarką w ogóle w ostatnich dziesięciu latach (od Niemiec i Austrii po Chorwację, od Włoch i Wielkiej Brytanii po Kalifornię). Żywa praca, studenci i akademicy są zatem tymi elementami, które wciąż doprowadzają kapitał do kryzysu. Także w szkolnictwie wyższym i nauce kryzys kapitału rodzi się zatem ze spotkania tych dwóch sił. Autonomicznej pracy, pracy edukacyjnej, autonomicznej organizacji nauki, autonomicznych obiegów produkcji wiedzy i pracy akademickiej z jednej strony. Z drugiej zaś, heteronomicznego kapitału, który dla samopomnażania potrzebuje cią̧łego dostępu do żywej 
pracy. Zażegnanie tego kryzysu może dokonać się wyłącznie przez emancypację pracy akademickiej.

\section{Krytyka}

Pojęcie krytyki jest nieodzownie związane z kryzysem. Raymond Williams (1988) zasugerował, że krytyka nie jest sądem, ale raczej praktyką związaną z daną podmiotowością, gdyż opiera się na zaangażowaniu i zajęciu określonego stanowiska. Jest formą praktyki teoretycznej, to znaczy podstawowym sposobem uprawiania wszelkiej teorii społecznej. Tak rozumiana krytyka jest konkretną interwencją w daną sytuację; czymś, co nie może zostać oddzielone od znaczenia kryzysu, gdyż jest wezwaniem do jego przezwyciężenia, a nie uchyleniem się przed jego skutkami czy próbą przerzucenia jego negatywnych efektów na cudze barki.

Sięgając jeszcze głębiej do znaczenia pojęcia krytyki, można ją przedstawić jako praktykę dekompozycji i rekompozycji. Jak stwierdził niegdyś Gerald Raunig, krytyka jest „wzajemnym oddziaływaniem między zawieszonym sądem a inwencją, między zdolnością do sądu, którego rozjaśnianie wykracza poza praktykę empirycznego rozróżniania oraz inwencja, która na nowo składa (znaczące) komponenty" (2008). By wyłożyć to nieco jaśniej, można przywołać wreszcie Michaela Hardta, który powyższe napięcie między zawieszeniem sądu a inwencja ujmuje w bardziej czytelny sposób: „Krytyka jest odwoławczym procesem destabilizującym nie tylko działające instytucje, ale także dominujące idee. Jednak do siły krytyki zawsze musi zostać dodany twórczy proces eksperymentowania z nowymi formami relacji społecznych i nowymi sposobami życia” (2012). To dopiero tak rozumiana krytyka może stać się podstawą dla jakiegokolwiek projektu alternatywy dla kapitalizmu, w tym kapitalizmu akademickiego.

\section{Marksistowskie badania szkolnictwa wyższego. Wewnątrz-przeciw-poza uniwersytet subsumowany pod kapitał}

Aby jednak w pełni uchwycić interesujące nas w tym numerze znaczenie krytyki, powinniśmy ponadto odnieść się do szczególnego fragmentu Ideologii niemieckiej. Marks i Engels tworząc swój projekt krytyczny, określili go w następujący sposób: „ræęeczywisty ruch, który znosi stan obecny. Warunki tego ruchu wynikają z obecnie istniejących przesłanek” (Marks, Engels 1961, 38). Ten wyjątkowy ruch obejmuje trzy wyróżnione momenty: a) jego podstawowym punktem odniesienia jest „stan obecny”, sam ruch jest osadzony wewnątrz niego, a więc przyjmuje konieczność zbadania go; b) głównym zadaniem krytyki jest „zniesienie” owego stanu, zajęcie antagonistycznego stanowiska, obrócenie się przeciw status quo; c) „warunki tego ruchu wynikają z obecnie istniejących przesłanek” - warunki możliwości zaistnienia tego ruchu krytyki 
są już dane, możliwość wyjścia „poza” gospodarkę kapitalistyczną lub jeden z jej obszarów są dane w obrębie samego kapitalistycznego sposobu produkcji.

Te trzy składowe moga pomóc w wyjaśnieniu podejścia metodologicznego, stojącego za marksistowskimi badaniami szkolnictwa wyższego. Krytyka stanowiąca ich punkt centralny obejmuje te trzy główne elementy. Po pierwsze, dąży do zdiagnozowania fenomenu kryzysu i wskazania mechanizmów, funkcjonujących „wewnątrz” podporządkowanego kapitałowi, neoliberalnego uniwersytetu. Do odkrycia ich podstawy, odsłonięcia wewnętrznych powiązań, rozłożenia ich i wskazania ich źródła. To właśnie w tym celu krytyczne badania szkolnictwa wyższego analizuja prace i publikacje, teorie i dyskursy, które współcześnie nadają kształt i wywierają wpływ w obszarze światowego szkolnictwa wyższego, a tym samym - tworza podwaliny dzisiejszego uniwersytetu. Może temu posłużyć metoda, podobna tej z Marksowskiej krytyki dokonań klasyków ekonomii politycznej, zastosowana w tym wypadku do śledzenia sprzeczności liberalnego myślenia w obrębie głównonurtowych badań szkolnictwa wyższego.

Po drugie, musza umieścić same siebie na pozycji podmiotowej, zwróconej „przeciwko” uniwersytetowi w kryzysie, jednocześnie odrzucając struktury podporządkowania, hierarchiczności, wywłaszczania i wyzysku, które pustoszą jego współczesną postać. Jak pisali Hardt i Negri: „Krytyka musi osiagnać poziom antagonizmu i rewolucyjnych podmiotowości, definiując i redefiniując ich przekształcenia, pokazując jak ich ruch i progresywne transformacje wciąż wchodzą w konflikt i niszczą nowe układy" (1994, 5-6). Krytyka musi podążać za walkami toczącymi się wewnątrz uniwersytetu i przeciwko niemu, współ-badać (Roggero 2011) z ich uczestnikami i uczestniczkami ich pragnienia, cele, sprzeczności, które obnażają, jak również horyzonty przyszłości, jakim dają początek.

Metoda negatywna jest niewystarczająca, dlatego też krytyka musi objąć również projekt pozytywny. Z tego też powodu trzeci aspekt obejmuje wysunięte wobec krytyki żądanie spojrzenia „poza” ograniczony horyzont, narzucony przez kryzys i wskazania w odpowiedzi immanentnych form stosunków społecznych, dostrzegalnych dzisiaj w zalążkowej postaci, które mogłyby dać podstawę pod uniwersytet przyszłości. Ten typ krytyki nie nakreśla utopijnych perspektyw, ale odkrywa elementy tego, co ma nadejść, w pustej skorupie starego uniwersytetu. Jak skrótowo ujęli to Hardt z Negrim, zadaniem tej krytyki jest „rozjaśnienie afirmatywnych i produktywnych figur, które wciąż wyłaniają się z walki pomiędzy dwiema klasami, pomiędzy dominacją a pragnieniem emancypacji”. Tego rodzaju projekt krytyki uniwersytetu w kryzysie został podjęty w tekstach zgromadzonych na kartach naszego numeru. 


\section{Krytyka ekonomii politycznej szkolnictwa wyższego i autonomiczna produkcja studenckiej podmiotowości}

Podstawowe niedostatki metodologiczne liberalnych projektów krytyki zostały wskazane przez Jossa Winna w tekście otwierającym nasz numer. Pisząc o pracy akademickiej jako Marksowskiej abstrakcji określonej, podejmuje się rozłożenia na części współczesnych diagnoz kryzysu uniwersytetu. Wskazuje na dwoistość tej kategorii, oznaczającej z jednej strony zestaw konkretnych praktyk (wykonywanie pracy akademickiej), z drugiej strony zaś określone ulokowanie pracownika akademickiego w całokształcie kapitalistycznych stosunków produkcji. Ostatecznie przeciwstawia się laborystycznym krytykom warunków pracy akademickiej, które, pragnąc znieść negatywne skutki oddziaływania logiki zysku w polu akademickim, nie przeciwstawiają się ich istocie i źródłu - kapitalistycznej pracy najemnej jako takiej. Droga do wyzwolenia uniwersytetu z warunków trapiącego go kryzysu wiedzie jedynie poprzez jej zniesienie i zakorzenienie wspólnotowych praktyk produkcji wiedzy w nowej, pokapitalistycznej formie bogactwa.

W kolejnym tekście tej części Paolo Do szkicuje ramy funkcjonowania globalnego reżimu szkolnictwa wyższego, którego heterogeniczność sprawia, że potrzebujemy podejścia wykraczającego poza binarna opozycję centrum i peryferii. W jej miejsce Do proponuje perspektywę skupiająca się raczej na całym szeregu przemieszczeń i dyslokacji, które z systemu szkolnictwa wyższego tworzą hierarchiczny stosunek. To właśnie w tych nowych ramach autor próbuje ukazać ekonomię polityczną wiedzy jako szczególny mechanizm współczesnej produkcji kapitalistycznej.

Krystian Szadkowski natomiast zwraca uwagę na wielość sposobów, w jakie kapitał, instrumentalizując wewnętrzne mechanizmy od stuleci rządzące polem uniwersyteckim, nadbudowuje się nad praca akademicką i wykorzystuje ją do celów samopomnażania. Wychodząc od walk toczonych przeciwko najistotniejszej współcześnie figurze akademickiego kapitału handlowego, czerpiącej pokaźne zyski z codziennej pracy milionów akademików na całym świecie, to jest firmie Reed-Elsevier, proponuje postoperaistyczną rewizję Marksowskich pojęć pracy produkcyjnej i nieprodukcyjnej w takich sektorach jak nauka i szkolnictwo wyższe.

Klamrę, spinającą rozważania dotyczące krytyki ekonomii politycznej szkolnictwa, znajdujemy zaś w tekście Richarda Halla, który kreśli inspirowaną pracami Davida Harveya sieć dialektycznych powiązań stosunków społecznych w obrębie podporządkowanego kapitałowi uniwersytetu. Hall śledzi to, w jaki sposób, na skutek neoliberalnych reform publicznego sektora nauki i szkolnictwa wyższego, dokonało się wpierw ograniczenie tradycyjnych wolności akademickich, a następnie zaś rozwinięcie wartości przyświecających projektowi wszechogarniającej konkurencji i pogoni za zyskiem, zakorzenionych w składowych momentach relacji akademickich. Nie poprzestaje jednak wyłącznie na tym. Wskazuje potencjał 
dóbr wspólnych i kooperatywnego uniwersytetu, w odwołaniu do których możliwe jest, jego zdaniem, odwrócenie wektorów sił w sektorze i doprowadzenie do zniesienia wyalienowanej postaci pracy akademickiej.

Z kolei problem możliwości zaistnienia rewolucyjnej podmiotowości w ramach systemu szkolnictwa wyższego podejmuja w drugiej części niniejszego numeru Sarah Amsler i Mike Neary, dwójka brytyjskich badaczy zaangażowanych w dwa projekty z pola radykalnej pedagogiki - „Student jako wytwórca” i Social Science Center. Czerpiąc zarówno z teorii marksistowskiej, jak i własnej praktyki edukacyjnej, dzielą się własnymi doświadczeniami budowania alternatywy dla zdominowanej przez kapitał nauki.

Teksty Amsler i Neary’ego, wyrastające z doświadczenia aktywizmu, uzupełniaja z kolei dwa świadectwa uczestników dawno już przebrzmiałych walk o alternatywę dla uniwersytetu. Franco Piperno, włoski działacz ruchu komunistycznego i uczestnik wydarzeń 1968 roku, przez pryzmat przeżytych zmagań i stawianego oporu, spogląda na współczesny kryzys włoskiego uniwersytetu nękanego przez kolejne cięcia wydatków publicznych. Zdaniem założyciela Potere Operaio, podobnie jak czterdzieści lat temu, również dziś kryzys otwiera przed studentami i studentkami droge do przebudowy uniwersytetu, jeśli tylko zdolni będą się zorganizować. Podobne zadanie znajdujemy we wczesnym eseju Waltera Benjamina, którego twórczość przypomina nam, że minione walki poprzednich pokoleń zaangażowanych studentów i studentek, jak również pracowników i pracownic uniwersytetu są nie tylko długiem domagającym się spłacenia, ale jednocześnie wyzwaniem, któremu kolejne pokolenia muszą sprostać, jeśli zrealizować ma się alternatywa znosząca stan obecny.

Czym są zatem marksistowskie badania szkolnictwa wyższego? W świetle prezentowanych w numerze tekstów nasuwa się jednoznaczna odpowiedź: interwencja w kryzys uniwersytetu. Określając jego zakres, zdając sprawę z obecnej sytuacji, odsłaniając produktywne sprzeczności, które rozwiązane moga zostać jedynie poprzez konkretne walki, dają one nie tylko nadzieję, ale przede wszystkim stwarzają warunki dla zniesienia obecnego stanu rzeczy i wyjścia poza jego ograniczenia. Choć w niniejszym numerze pomaga nam w tym przyjęcie perspektywy "wewnątrz-przeciw-poza", to wciąż domaga się ona produktywnej syntezy. Ta jednak z konieczności nie może wydarzyć się na łamach jakiegokolwiek czasopisma, ale musi zmaterializować się w naszej codziennej praktyce. Oddając niniejszy numer w wasze ręce, liczymy, że właśnie w tym może okazać się Wam pomocny. 


\section{Wykaz literatury}

Althusser, Louis. 2006. Ideologie i aparaty ideologicæne państwa. Tłum. Andrzej Staroń. Warszawa: Studenckie Koło Filozfii Marksistowskiej. http://www.filozofia.uw.edu.pl/skfm/publikacje/althusser05.pdf.

Antonowicz, Dominik. 2015. Między siła globalnych procesów a lokalnq tradycja. Polskie słkolnictwo wy šsze w dobie przemian. Toruń: Wydawnictwo Naukowe Uniwersytetu Mikołaja Kopernika.

Ball, Stephen i Youdell, Deborah. 2008. Hidden Privatisation in Public Education. Brussels: Education International.

Barnett, Ronald. 2015. „In Search of a Public: Higher Education in a Global Age.” W O. Filippakou i G. Williams (red.), Higher Education as a Public Good. Critical Perspectives on Theory, Policy and Practice (s. 15-28). New York: Peter Lang.

Edu-factory Collective. 2009. Towards a Global Autonomous University. New York: Autonomedia.

Hall, Richard. 2015. „The University and the Secular Crisis.” Open Library of Humanities 1(1).

Hardt, Michael. 2012. „Komunizm jest bezwględną krytyką wszystkiego, co istnienie.” Praktyka Teoretyczna, http:/ / www.praktykateoretyczna.pl/michael-hardt-komunizm-jestbezwzgledna-krytyka-wszystkiego-co-istnieje/

Hardt, Michael i Negri, Antonio. 1994. Labor of Dionysus. A Critique of the State-Form. Minneapolis: University of Minnesota Press

Harvey, David. 2014. Seventeen Contradictions and the End of Capitalism. London: Oxford University Press.

Holloway, John. 2010. Crack Capitalism. London: Pluto Press.

Jongbloed, Ben. 2003. „Marketisation in Higher Education: Clark's Triangle and the Essential Ingredients of Markets." Higher Education Quarterly 57(2): 110-135.

Leslie, Larry i Slaughter, Sheila. 1998. Academic Capitalism. Politics, Policies and Entrepreneurial University. Baltimore: Johns Hopkins University Press.

Mandel, Ernst. 1999. Late Capitalism. London-New York: Verso.

Marginson, Simon. 2006. „Putting „Public” Back into the Public University.” Thesis Eleven 84: 44-59.

Marks, Karol. 1956. Kapitał, t. 1. Warszawa: Książka i Wiedza.

Marks, Karol i Engels, Fryderyk. 1961. „Ideologia niemiecka”. W MED, t. 3. Warszawa: Książka i Wiedza.

Schrecker, Ellen. 2010. The Lost Soul of Higher Education. Corporatization, the Assault on Academic Freedom, and the End of the American University. New York: The New Press.

Szadkowski, Krystian. 2015a. Uniwersytet jako dobro wspólne. Warszawa: PWN.

Szadkowski, Krystian. 2015b. „Teza o hybrydyzacji tego, co publiczne i tego, co prywatne w szkolnictwie wyższym oraz jej konsekwencje. Próba krytyki." Nauka i sæłkolnictwo wy šsze 46(2): 75-120.

Oliveira, Marcos Barbosa. 2013. „On the Commodification of Science: The Programmatic Dimension." Science \& Education 22(10): 2463-2483.

Raunig, Gerald. 2008. „What is critique? Suspension and recomposition in textual and social machines." Transversal, http://eipcp.net/transversal/0808/raunig/en 
Rikowski, Glenn. 1997. „Scorched Earth. Prelude to Rebuilding Marxist Educational Theory." British Journal of Sociology of Education 18(4): 551-574.

Roggero, Gigi. 2011a. Pięć tez o dobru wspólnym. Tłum. Piotr Juskowiak, Krystian Szadkowski. Praktyka Teoretyczna 4: 69-83.

Roggero, Gigi. 2011b. The Production of Living Knowledge. Philadelphia: Temple University Press. Williams, Raymond. 1988. Resources of Hope. Culture, Democracy, Socialism, London: Verso. 
Krystian Szadkowski - adiunkt w Instytucie Filozofii UAM, badacz Centrum Studiów nad Polityką Publiczną UAM. Autor książki Uniwersytet jako dobro wspólne. Podstawy krytycznych badań nad szkolnictwem wy żsaym (Wydawnictwo Naukowe PWN 2015). Redaktor Praktyki Teoretycznej.

\title{
DANE ADRESOWE:
}

Krystian Szadkowski

Centrum Studiów nad Polityką Publiczną UAM

ul. Szamarzewskiego 89c

60-568 Poznań

EMAIL: krysszad@amu.edu.pl

Jakub Krzeski - student Międzyobszarowych Indywidualnych Studiów Humanistycznych i Społecznych UW, w ramach których studiuje filozofię i kulturoznawstwo. Interesuje się przede wszystkim marksizmem postoperaistycznym i społeczną myślą nowożytną. Redaktor Praktyki Teoretycznej.

\section{DANE ADRESOWE:}

Jakub Krzeski

Kolegium Międzyobszarowych Indywidualnych Studiów Humanistycznych i Społecznych UW ul. Dobra 72

00-312 Warszawa

EMAIL: j.m.krzeski@gmail.com

CYTOWANIE: Szadkowski, Krystian i Krzeski, Jakub. 2015. „Czym są marksistowskie badania nad szkolnictwem wyższym?.” Praktyka Teoretyczna 4(18): 8-17.

DOI: $10.14746 /$ prt.2015.4.0

AUTHOR: Krystian Szadkowski i Jakub Krzeski

TITLE: What is the Marxist Higher Education Research?

\begin{abstract}
In this short introduction to the thematic issue of Theoretical Practice we draw on the Marxist concept of critique to explain how Marxist higher education research could be understood as a constituting practice within-against-beyond the contemporary university in crisis.
\end{abstract}

KEYWORDS: critique, crisis, critical higher education research, Marxism, method 